\title{
Learning Surgical Anatomy in the Field of Microsurgical Reconstructive Surgery. A new Pedagogic Method on Human Fresh Cadavers
}

\author{
Aprendizaje de la Anatomía Quirúrgica en la Cirugía Microquirúrgica Reconstructiva. Un Nuevo \\ Método Pedagógico en Cadáveres Humanos Frescos
}

Carine Laroche* \& Christian Vacher*

LAROCHE, C. \& VACHER, C. Learning surgical anatomy in the field of microsurgical reconstructive surgery. A new pedagogic method on human fresh cadavers. Int. J. Morphol., 32(2):678-683, 2014.

SUMMARY: Microsurgical vascular anastomosis in reconstructive surgery learning is usually based on rat dissection. But this technique does not allow dissection of the flap, preparing of the recipient vessels training, and suturing in conditions as realistic as possible of the surgery. The aim of this study was to describe a technique of surgical anatomy learning on human fresh cadavers, easy to perform and to evaluate its pedagogic interest. In the first part of the study, six fresh cadavers have been dissected simulating 6 forearm flaps with growing difficulty. In the second part of the study, 30 residents in surgery were evaluated on their ability to recognize main anatomic structures and to perform microsurgical anastomosis, of forearm flaps anastomosed on facial vessels. Concerning the first part of the study, it has been possible to use this method in all cases. The second part of the study showed that all the residents performed the dissection of the flap with success. The main anatomic structures (origin of the radial and ulnar arteries, companion veins of radial artery) have been identified by all the residents. The cephalic vein, the median antebrachial vein and the superficial branch of the radial nerve have been identified by most of the residents. The lateral antebrachial cutaneous nerve has been identified by only 12 residents. The arterial anastomosis has been performed with success in most cases (11/15 dissections), and the venous anastomosis in only $5 / 15$ dissections. Surgical anatomy learning in the field of microvascular reconstructive surgery on human fresh cadavers is possible, easy to organize in a anatomy department. This method has to be considered as a useful complement of microvascular anastomosis learning on rats.

\section{KEY WORDS: Anatomy; Cadavers; Microsurgery; Reconstructive surgery; Teaching.}

\section{INTRODUCTION}

Dissection on fresh cadavers are very useful in teaching anatomy to medical students all over the world (Reveron, 2010), and also to improve the surgical skills of residents in surgery. Microsurgical vascular anastomosis learning is usually based on rats dissections in France and in the USA (Goosens et al., 1990). This pedagogic method is very satisfying to give experience to the residents with the use of the microscope and the microvascular clamps, and to make them improve their technical ability with no failure risk for the patients. But it is very different to make a vascular anastomosis on rat vessels and to make it on human material between the flap pedicle and the recipient vessels in real anatomic conditions. Residents also need to make themselves the dissection of the flap, to improve their knowledge of the anatomic basis of the flap and to prepare the recipient vessels. The aim of this study was to describe a new pedagogic method of microsurgical reconstructive surgery training in the department of anatomy, easy to perform, using human fresh cadavers and colored latex injections, and to evaluate its pedagogic interest for residents in surgery.

\section{MATERIAL AND METHOD}

In the first part of the study, six fresh cadavers have been dissected ( 5 females and 1 male), in order to evaluate the feasibility of this simulation technique. These dissections have been performed in all cases by the same two surgeons.

In the first case (case 1) we performed the harvesting of a right forearm flap, based on the radial artery and median antebrachial vein. After elevation of the flap from distal to 
proximal, the radial artery has been isolated and dissected just after its origin, sectioned, and anastomosed to itself using 8:0 stitches with the help of magnifying glasses (2.5x). After performing the suture, the part of the radial artery proximal to the suture has been cannulated (Fig. 1) and an injection of

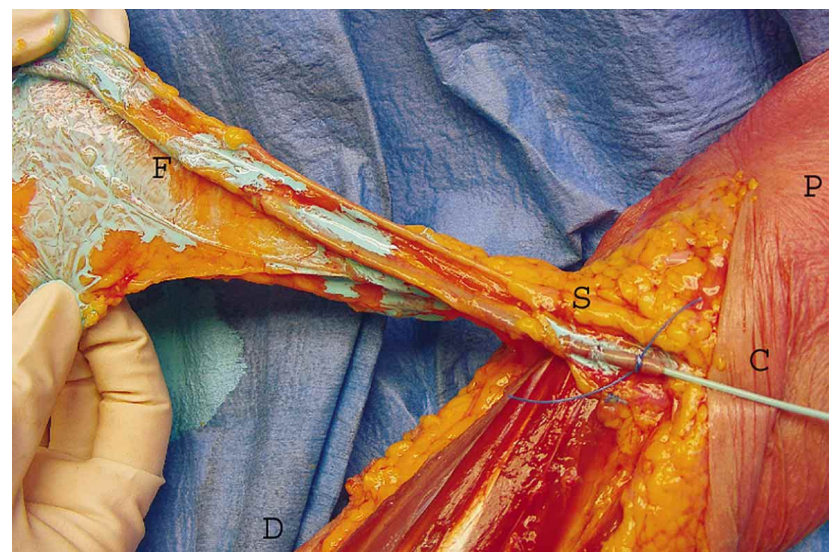

Fig. 1. After performing arterial suture of the radial artery, the part of the radial artery proximal $(\mathrm{P})$ to the suture $(\mathrm{S})$ has been cannulated (C) and an injection of colored latex has been performed inside the artery to see if there was a coloration of the distal part (D) of the artery and the flap (F) by colored latex (case 1 ).

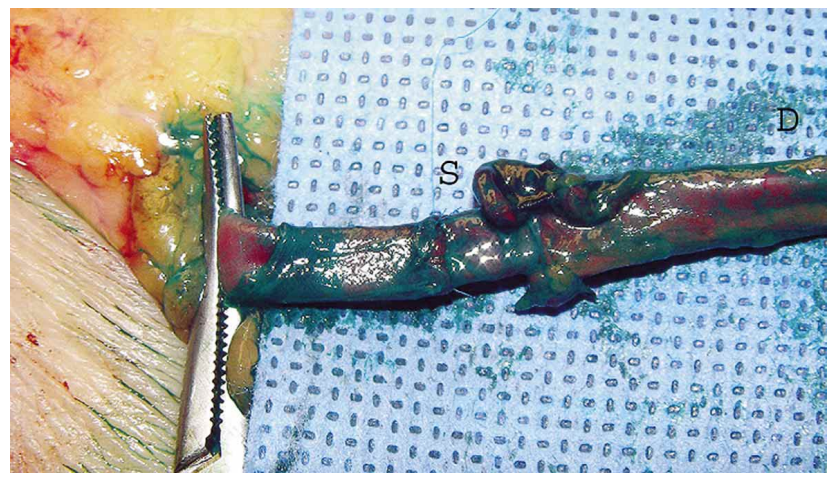

Fig. 2. Focus on the suture area after injection of colored latex inside the artery showing a coloration of the part of the artery distal (D) to the suture (S) (case 1).

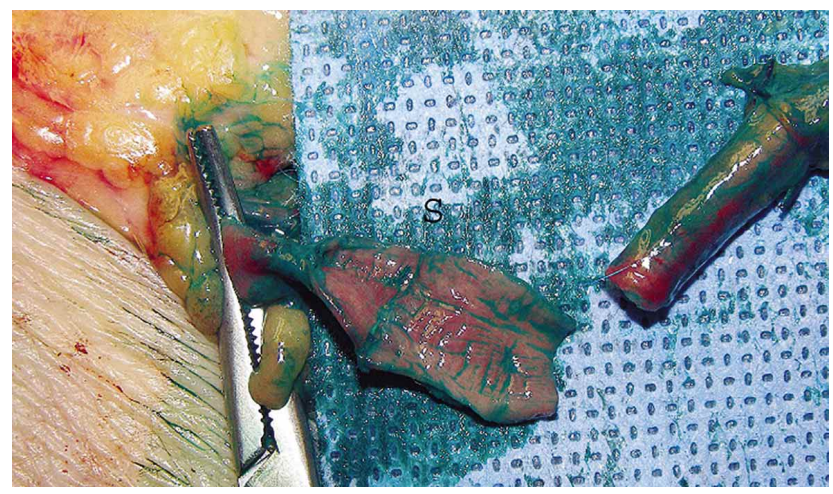

Fig. 3. Resection of the suture (S) area and evaluation of the quality of the suture under direct vision (case 1). liquid colored latex has been performed inside the artery to see if there was a coloration of the distal part of the artery and the flap by colored latex (Fig. 2). The part of the artery concerned by the suture has been then resected and the quality of the suture has been controlled under direct vision (Fig. 3).

In the second case (case 2), we also harvested a forearm flap, based on the radial pedicle and on median antebrachial vein. After elevation of the flap, the median forearm vein has been dissected and isolated in the anterior side of the wrist, sectioned and anastomosed to itself using 9:0 stitches with the help of magnifying glasses (2.5x). After the suture, the part of the vein distal to the suture has been canulated and injected with liquid colored latex to control the coloration of the proximal part of the vein. As in case one, the suture area has been resected to control the quality of the suture.

In the next two cases (cases 3 and 4) we performed the harvesting of a forearm flap, with dissection of the radial pedicle and median antebrachial vein vein. After elevation of the flap from distal to proximal, the radial artery and the median antebrachial vein have been sectioned in the anterior side of the elbow. These two vessels have been anastomosed to themselves using 8:0 stitches for the artery and 9:0 stitches for the vein. The arterial suture has been tested the same way than in case 1 and the vein the same way than in case 2 .

In the fifth and sixth cases (case 5 and 6), we performed the same technique of harvesting of a forearm flap than in former cases, but at the same time a cervical incision has been made and the facial pedicle has been dissected. After section of the radial artery and the median antebrachial vein, these vessels have been anastomosed to the facial vessels. The sutures have been controlled the same way than in former cases.

In the second part of the study, a course has been organized for 30 residents in surgery. Before performing the dissections, the residents had a two hours course on the anatomic basis, and the surgical technique of the flap and had to answer a questionnaire about their experience in reconstructive surgery (Table I). The harvesting of a forearm flap and anastomose of this flap with the facial vessels have been performed by the 30 residents working by groups of two (Fig. 4). After the dissection, the residents were evaluated on their ability to identify main anatomic structures concerned by the dissection. The arterial anastomose has been tested by injection of liquid colored latex from the facial artery to the forearm flap and the venous anastomose by injection of liquid colored latex from the vein of the flap to the facial vein (Table I). 


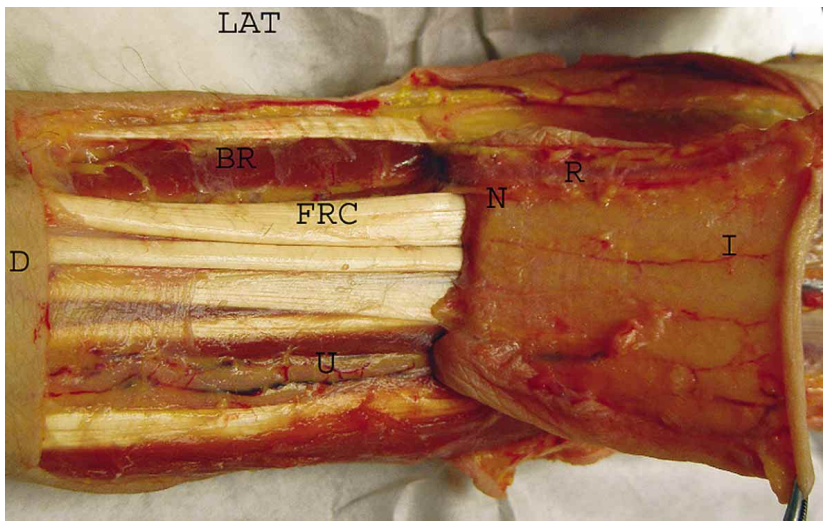

Fig. 4. Harvesting of a right forearm flap, based on the radial artery (R) and median antebrachial vein (I) from distal (D) to proximal. On the lateral border (LAT) of the forearm, the brachioradialis (BR) and the flexor carpi radialis (FRC) muscles are dissected and the superficial branch of the radial nerve $(\mathrm{N})$ has been identified. The ulnar pedicle $(\mathrm{U})$ is also visible on the medial border of the forearm.

Table I. Questionnaire.

\begin{tabular}{|c|c|}
\hline Questions & Answers \\
\hline \multicolumn{2}{|l|}{ To answer before the dissection } \\
\hline \multirow[t]{3}{*}{ Specialty } & Plastic surgery \\
\hline & Otorhinolary ngology \\
\hline & Maxillofacial surgery \\
\hline Year of formation in the specialty & 1 year to 7 \\
\hline \multirow[t]{2}{*}{ Former formation to microsurgery on rats } & Microsurgery course already passed \\
\hline & No education in microsurgery \\
\hline \multicolumn{2}{|l|}{ To answer after the dissection } \\
\hline \multicolumn{2}{|c|}{ Did you identify the following anatomic structures : } \\
\hline \multicolumn{2}{|l|}{ Origin of the radial artery : } \\
\hline \multicolumn{2}{|l|}{ Origin of the ulnar artery : } \\
\hline \multicolumn{2}{|l|}{ Companion veins of radial artery: } \\
\hline \multicolumn{2}{|l|}{ Cephalic vein : } \\
\hline \multicolumn{2}{|l|}{ Median antebrachial vein : } \\
\hline \multicolumn{2}{|l|}{ Superficial branch of the radial nerve : } \\
\hline \multicolumn{2}{|l|}{ Lateral antebra chial cutaneous nerve : } \\
\hline Results of the arterial anastomosis : & Succeed or not \\
\hline Results of the venous anastomosis & Succeed or not \\
\hline
\end{tabular}

Table II. Answers to the questionnaire

\begin{tabular}{|c|c|}
\hline Questions & Answers (n = 30 residents ) \\
\hline \multirow[t]{3}{*}{ Specialty of the 30 residents } & Plastic surgery : $10 / 30$ \\
\hline & Otorhinolaryngology : $8 / 30$ \\
\hline & Maxillofacial surgery : $12 / 30$ \\
\hline Mean year of formation in the specialty & 3,62 years \\
\hline \multirow[t]{2}{*}{ Former formation to microsurgery on rats } & Microsurgery course already passed : $15 / 30$ \\
\hline & No education in microsurgery : $15 / 30$ \\
\hline \multicolumn{2}{|c|}{$\begin{array}{l}\text { To answer after the dissection ( } 15 \text { dissections performed by } \\
\text { Identification of the following anatomic structures }\end{array}$} \\
\hline \multicolumn{2}{|l|}{ Origin of the radial artery $: 30 / 30$} \\
\hline \multicolumn{2}{|l|}{ Origin of the ulnar artery $: 30 / 30$} \\
\hline \multicolumn{2}{|l|}{ Companion veins of radial artery $: 30 / 30$} \\
\hline \multicolumn{2}{|l|}{ Cephalic vein : $24 / 30$} \\
\hline \multicolumn{2}{|l|}{ Median antebrachial vein : $19 / 30$} \\
\hline \multicolumn{2}{|l|}{ Superficial branch of the radial nerve : $25 / 30$} \\
\hline \multicolumn{2}{|l|}{ Lateral antebrachial cutane ous nerve : $12 / 30$} \\
\hline Results of the arterial anastomosis & Succeed : 11 / Failed : 4 \\
\hline Results of the venous anastomosis & Succeed : 5 / Failed : 10 \\
\hline
\end{tabular}




\section{RESULTS}

In the first six cases, the diffusion of the colored latex across the anastomose was good.

The results of the resident dissections are summarized on Table II. Half residents had an education in microsurgery (on rats). The main anatomic structures that are necessary to recognize during the dissection of the forearm flap have been identified by all the residents (origins of the radial and ulnar arteries and companion veins of radial artery). The superficial veins of the flap have been more difficult to identify for the residents. The cephalic vein has been identified by 24 residents and the median antebrachial vein by only 19 residents. The superficial branch of the radial nerve has been identified by 25 residents and the lateral antebrachial cutaneous nerve by 12 residents. The arterial anastomosis between the facial and the radial arteries have been performed with success in 11 dissections ( 22 residents). The venous anastomosis between the facial vein and the median antebrachial vein or the cephalic vein has been performed with success in only 5 dissections (10 residents). When the residents performed the arterial and venous anastomosis, in all cases they have had a former formation to microsurgery on rats.

\section{DISCUSSION}

In this study we described a new surgical anatomy training model of microvascular anastomosis based on fresh cadaver dissections and colored latex injection of the microvascular suture. This training method has been validated on residents in surgery. Most of reconstructive surgeons have learned microsurgery on animal models. Rats have been used for a long time for reconstructive microsurgical training. The principle vessels that have been used in rats are epigastric vessels transposed to the common carotid artery and jugular vein (Araico-Laguillo et al., 1981), the renal vessels transposed to the inguinal region as in renal transplantation, and the rat tail (Bao, 1995; Zhang et al., 1998). Animals models are very useful for basic microvascular anastomosis learning but, because the growing ethical awareness and stricter animal protection, other training models have been found. Some authors proposed to use animal cadaver vessels perfused in vitro for microvascular training as legs vessels of slaughtered pigs (Steffens et al., 1992), chicken wing vessels (Olabe \& Olabe, 2009; Krishnan et al., 2004), porcine coronary arteries (Schoffl et al., 2006). Other authors described synthetic models to simulate the live vessels (Korber \&
Kraemer, 1989; Weber et al., 1997; Meier et al., 2004; Matsamura et al., 2009; Spetzer et al., 2011) and to reduce the number of animals required for microsurgical training. All these techniques are useful for microvascular anastomosis training but they are not able to simulate the anatomic conditions of the anastomosis in a patient and to improve the surgical anatomic knowledge of the residents. In free flap reconstructive surgery, preparing recipient vessels, dissecting the flap are also important to teach to young residents. Whereas, teaching courses in the field of free flaps transfers are particularly challenging because -1 the surgeon needs a complete knowledge of the flap anatomy -2 , he needs a high requirement of dexterity and microsurgery skills -3 he has to learn tenacity because of the long surgery time which is necessary. Wolff et al. (2008), used the Thiel embalming technique in order to perform free flaps dissections including the microvascular anastomosis. These authors performed nine free flaps on each of thirty cadavers. The advantages of this method are, it is real training on free flaps and a suitable condition for both macroscopic and microscopic dissection. But the fixation procedure of this technique needs up to six months and produces high costs. More over, dissection time and microvascular suture time are distinct which is different of real practice. Tellioglu et al. (2009), described the use of fixed and fresh cadavers to perform microvascular training on human vessels. For the authors, the anastomoses cannot be assessed in the dynamic vascular conditions. They consider that their training is easier to perform than clinical cases. In our opinion this technique is only a microvascular training but it is not a free flap dissection training. Olabe $e t$ al. (2009), developed a "brain infusion model" using cadaveric brains with cannulation of carotid and vertebral arteries allowing water infusion of the vessels during the dissection.

The first human circulation model was described by Garett (2001) followed by Aboud et al. (2002), creating a dynamic pulsating cerebral model. The authors' model is a simplified useful and inexpensive alternative. But this technique is suitable for microneurosurgical training and, to our knowledge, there is no "whole body infusion model". In our study we described a new technique allowing the dissection of the flap, the preparation of the recipient vessels, the microvascular suturing in conditions as realistic as possible because of the use of fresh cadavers. In addition this technique makes the checking of the permeability of the anastomosis possible after colored latex injection. The evaluation of this pedagogic method by the residents in our study confirms the interest of this procedure in addition 
to the learning of microvascular sutures on rats. In order to improve the knowledge of reconstructive microvascular procedures and anatomic basis of free flaps procedures in young residents, it seems important to us to propose this type of pedagogic method in our anatomy departments. The organization of a diploma based on dissections of free flaps of growing difficulty on fresh cadavers in the real conditions of the surgery could be important for the learning of reconstructive microsurgery. This diploma has to be reserved to residents who have already done a diploma of microsurgery on rat dissections. Goosens et al., have conducted a survey to assess the present level of instruction in microsurgery in the USA. They concluded that every student receive a 40 hour basic course followed by advanced course. We suggest that our training model in the anatomy department takes place in advanced course because it is in accordance to the three points required in the field of complete reconstructive microsurgery training : - 1 a free flap dissection, - 2 a microsurgery training, -3 anatomic conditions as close as possible to the real surgery.

LAROCHE, C. \& VACHER, C. Aaprendizaje de la anatomía quirúrgica en la cirugía microquirúrgica reconstructiva. Un nuevo método pedagógico en cadáveres humanos frescos. Int. J. Morphol., 32(2):678-683, 2014.

RESUMEN: La anastomosis microquirúrgica vascular en el aprendizaje de cirugía reconstructiva generalmente se basa en la disección de la rata. Sin embargo, esta técnica no permite la disección del colgajo, la preparación de la formación de vasos receptores, y la sutura en condiciones similares a la cirugía. El objetivo de este estudio fue describir una técnica de enseñanza de la anatomía quirúrgica en cadáveres frescos, fáciles de realizar y con el objetivo de evaluar su interés pedagógico. Inicialmente en el estudio, seis cadáveres frescos fueron disecados simulando 6 colgajos de antebrazo con creciente dificultad. En la segunda parte del estudio, 30 residentes de cirugía fueron evaluados en su capacidad para reconocer las principales estructuras anatómicas y realizar anastomosis microquirúrgica de los colgajos del antebrazo anastomosados en vasos faciales. En la primera parte del estudio, fue posible usar este método en todos los casos. Durante la segunda parte del estudio todos los residentes realizaron la disección del colgajo con éxito. Las principales estructuras anatómicas (origen de las arterias radial y ulnar, venas acompañantes de la arteria radial) fueron identificadas por todos los residentes. La vena cefálica, la vena mediana del antebrazo y la rama superficial del nervio radial fueron identificados por la mayoría de los residentes. El nervio cutáneo antebraquial lateral fue identificado por 12 residentes. La anastomosis arterial fue realizada con éxito en la mayoría de los casos(11/15 disecciones), y la anastomosis venosa en sólo 5/15 disecciones. La docencia en anatomía quirúrgica y en el campo de la cirugía reconstructiva microvascular en cadáveres frescos es posible y fácil de organizar en un departamento de anatomía. Este método debe ser considerado como un complemento en la docencia de anastomosis microvascular en ratas.

PALABRAS CLAVE: Anatomía; Cadáveres; Microcirugía; Cirugía reconstructiva; Docencia.

\section{REFERENCES}

Aboud, E.; Al-Mefty, O. \& Yas, argil, M. G. New laboratory model for neurosurgical training that simulates live surgery. $J$. Neurosurg., 97(6):1367-72, 2002.

Araico-Laguillo, J.; Andrade-Gómez, F.; Arámbula-Alvarez, I. H. \& Ochoa-Díaz López, E. Training program for free transfer of skin grafts by microvascular anastomosis. Arch. Invest. Med. (Mex.), 12(3):323-39, 1981.

Bao, J. Y. Rat tail: a useful model for microvascular training. Microsurgery, 16(2):122-5, 1995.

Garret, H. E. Jr. A human cadaveric circulation model. J. Vasc. Surg., 33(5):1128-30, 2001.

Goossens D. P.; Gruel S. M. \& Rao V. K. A survey of microsurgery training in the United States. Microsurgery, 11(1):2-4, 1990.

Korber, K. E. \& Kraemer, B. A. Use of small-caliber polytetrafluoroethylene (Gore-Tex) grafts in microsurgical training. Microsurgery, 10(2):113-5, 1989
Krishnan, K. G.; Dramm, P. \& Schackert, G. Simple and viable in vitro perfusion model for training microvascular anastomoses. Microsurgery, 24(4):335-8, 2004.

Meier, S. A.; Lang, A. \& Beer, G. M. Polyurethane vessels for microvascular surgical training to reduce animal use. ALTEX, 21(3):135-8, 2004

Matsumura, N.; Hayashi, N.; Hamada, H.; Shibata, T.; Horie, Y. \& Endo, S. A newly designed training tool for microvascular anastomosis techniques: Microvascular Practice Card. Surg. Neurol., 71(5):616-20, 2009.

Olabe, J. \& Olabe, J. Microsurgical training on an in vitro chicken wing infusion model. Surg. Neurol., 72(6):695-9, 2009.

Olabe, J.; Olabe, J. \& Sancho, V. Human cadaver brain infusion model for neurosurgical training. Surg. Neurol., 72(6):700-2, 2009.

Reveron, R. R. Anatomical dissection: a positive experience for 
Venezuelan first year medical students. Int. J. Morphol., 28(1):213-7, 2010.

Schoffl, H.; Hager, D.; Hinterdorfer, C.; Dunst, K. M.; Froschauer, S.; Steiner, W.; Kwasny, O. \& Huemer, G. M. Pulsatile perfused porcine coronary arteries for microvascular training. Ann. Plast. Surg., 57(2):213-6, 2006.

Spetzger, U.; von Shilling, A.; Brombach, T. \& Winckler, G. Training models for vascular microneurosurgery. Acta. Neurochir. Suppl., 112:115-9, 2011.

Steffens, K.; Koob, E. \& Hong, G. Training in basic microsurgical techniques without experiments involving animals. Arch. Orthop. Trauma Surg., 111(4):198-203, 1992.

Tellioglu, A. T.; Eker, E.; Cimen, K.; Comert, A.; Karaeminogullari, G. \& Tekdemir, I. Training model for microvascular anastomosis. J. Craniofac. Surg., 20(1):238-9, 2009.

Weber, D.; Moser, N. \& Rösslein, R. A synthetic model for microsurgical training: a surgical contribution to reduce the number of animal experiments. Eur. J. Pediatr. Surg., 7(4):2046, 1997.

Wolff, K. D.; Kesting, M.; Mücke, T.; Rau, A. \& Hölze, F. Thiel embalming technique: a valuable method for microvascular exercise and teaching of flap raising. Microsurgery, 28(4):2738, 2008.

Zhang, F.; Chin, B. T.; Ho, P. R.; Costa, M. A.; Lineaweaver, W. C. \& Buncke, H. J. Rat tail replantation as a training model for microvascular procedures of digit replantation. Microsurgery, 18(6):364-7, 1998.

\author{
Correspondence to : \\ Pr. Christian Vacher \\ Service de Chirurgie Maxillo-faciale et stomatologie \\ Hôpital Beaujon, AP-HP \\ 100 Bd Général Leclerc \\ 92118 Clichy Cedex \\ FRANCE
}

Phone: 33-1-40875671

Email: christian.vacher@bjn.aphp.fr

Recibido: 26-03-2014

Aceptado: 03-05-2014 